\title{
Effect of cytokines and growth factors on the secretion of inhibin A, activin A and follistatin by term placental villous trophoblasts in culture
}

\author{
A Mohan, J Asselin, I L Sargent, N P Groome ${ }^{1}$ and S Muttukrishna \\ Nuffield Department of Obstetrics and Gynaecology, University of Oxford, John Radcliffe Hospital, Oxford OX3 9DU, UK and ${ }^{1}$ Oxford Brookes University, \\ Headington, Oxford, UK \\ (Correspondence should be addressed to S Muttukrishna who is now at Department of Obstetrics and Gynaecology, Royal Free-UCL Medical School, \\ 86-96 Chenies Mews, London WC1, UK; Email: s.muttukrishna@ucl.ac.uk)
}

\begin{abstract}
Objective: Maternal serum inhibin A and activin A are higher in pre-eclampsia than in normal pregnancy. The placenta is a source of these proteins in pregnancy. The aim of this study was to investigate the effect of growth factors and proinflammatory cytokines that are raised in pre-eclampsia on the secretion of dimeric inhibin A, activin A and follistatin by villous cytotrophoblasts in culture. Design and methods: Villous cytotrophoblasts were prepared from term placentae and cultured in serumfree media. Cells were treated with increasing concentrations of tumour necrosis factor (TNF) $\alpha$, interleukin (IL)- $1 \beta$, transforming growth factor (TGF)- $\beta 1$, granulocyte and monocyte colonystimulating factor (GMCSF), inhibin A, activin A and follistatin for 2 days. Culture supernatants were assayed for human chorionic gonadotrophin (hCG), inhibin A, activin A and follistatin as appropriate. Experiments were repeated at least three times with each cytokine or growth factor and the data pooled. Results: Cytotrophoblasts syncytialise and spontaneously secrete hCG, inhibin A and activin A in culture. Follistatin levels were $<20 \mathrm{pg} / \mathrm{ml}$ in most experiments. Activin A secretion was increased in culture in a dose-dependent manner by IL-1 $\beta(\sim 150 \%, P<0.05)$, TNF- $\alpha(\sim 35 \%, P=0.02)$ and GMCSF $(\sim 100 \%, P<0.01)$. hCG secretion was inhibited in a dose-dependent manner by TNF- $\alpha$ $(50 \%, P<0.05)$. Inhibin A was stimulated by $\mathrm{IL}-1 \beta(\sim 30 \%, P=0.05)$. Inhibin A, activin A, follistatin or TGF- $\beta 1$ did not have a significant effect on any measured parameters.

Conclusions: These data show that inflammatory cytokines increase the secretion of activin A by trophoblasts in culture. The presence of very low levels, or no follistatin $(<20 \mathrm{pg} / \mathrm{ml})$ in the culture media suggests 'free' activin A could have autocrine/paracrine effects on cytotrophoblasts. Inhibin A secretion was stimulated by IL-1 $\beta$. However, absence of an effect by the other cytokines investigated on inhibin A in this study suggests that the mechanism(s) involved in increasing maternal circulating levels of inhibin A and activin A in pre-eclampsia are controlled differentially.
\end{abstract}

European Journal of Endocrinology 145 505-511

\section{Introduction}

We have previously shown that high levels of circulating inhibin A (1) and activin A (2) are present in the maternal circulation throughout pregnancy and that, at least in early pregnancy, the source of these proteins is the feto-placental unit (3-5). High concentrations of follistatin are also found in the maternal blood in pregnancy (6). We have shown that maternal serum inhibin $\mathrm{A}$ and activin $\mathrm{A}$ are higher in pre-eclampsia than in normal pregnancy (7).

Several studies have described the presence of inhibin and activin subunits and their mRNA in placental cells (8-10). Petraglia et al. (11) have shown that human placenta expresses the inhibin $\alpha$ and $\beta A$-subunit proteins as early as the first trimester of pregnancy. They have also shown that placental tissue at term expresses the highest levels of $\alpha$ - and $\beta A$ subunits. In the same study, inhibin $\alpha$-subunit was localised in the villous cytotrophoblast, inhibin $\beta B-$ subunit was observed in the syncytial layer of the villi and inhibin $\beta A$-subunit was widely distributed in both cell types. Tovanabutrra et al. (12) have shown that the concentrations of bioactive inhibin (based on a pituitary follicle-stimulating hormone inhibition assay) in the placenta remain fairly constant throughout pregnancy.

Human placental trophoblast production of immunoreactive (ir)-inhibin (dimeric inhibins+ monomeric $\alpha$-subunit forms) has been previously reported (13-15). However, the studies described above measured inhibin secretion by term placental 
trophoblast using an RIA ('Monash' RIA) (16) that does not distinguish between biologically active dimeric inhibins and inert monomeric $\alpha$-subunits $(15,17)$. Inhibins measured using this assay are referred to as ir-inhibins to distinguish them from the specific molecular forms inhibin A and inhibin B.

The development of sensitive and highly specific ELISAs for potentially bioactive dimeric inhibin A, inhibin B, activin A and follistatin (18-21) has now enabled us to measure these hormones in circulation in the menstrual cycle (18-21) and normal pregnancy $(1,2,4,6)$. We have also shown that at term, placental homogenates contain high concentrations of inhibin A (1) and activin A (2) and others have reported that term placental trophoblasts secrete dimeric activin A in vitro (22). Keelan et al. (22) also reported that there was a $31 \mathrm{kDa}$ band running in parallel to human recombinant inhibin in their Western blotting experiments conducted with trophoblast culture supernatant, suggesting the presence of dimeric inhibin $A$ and/or inhibin B in the culture medium. These studies confirm that placenta is a source of inhibin A and activin A in pregnancy.

We have cultured cytotrophoblasts from term placentae. Cytotrophoblasts syncytialise (a process where mononuclear cytotrophoblasts fuse and form a multinuclear syncytium) in culture and secrete increasing concentrations of human chorionic gonadotrophin (hCG), inhibin A, activin A and follistatin $(23,24)$ in a time-dependent manner. We are interested in investigating the mechanism(s) involved in raising maternal circulating levels of inhibin A and activin A in pre-eclampsia.

Previous studies have shown that inflammatory cytokines are increased in pre-eclampsia compared with normal pregnancy (25). Hence, in this study we set out to determine whether these findings are linked. We have addressed the following three questions: (i) do inflammatory cytokines that are increased in the circulation of pre-eclamptic women (tumour necrosis factor (TNF)- $\alpha$ and interleukin (IL)-1 $\beta$ ) increase inhibin $A$, activin $A$ and follistatin secretion by trophoblasts, (ii) do cytokines that are reported to facilitate (granulocyte and monocyte colony-stimulating factor (GMCSF)) and inhibit (transforming growth factor (TGF)- $\beta 1$ (26)) syncytial formation affect inhibin A, activin $A$ and follistatin secretion, and (iii) are there autocrine/paracrine effects of inhibin A, activin A and follistatin on trophoblasts in culture?

\section{Materials and methods}

\section{Primary culture of human placental cells}

Isolation of human placental cells was performed according to a modified method of Kliman et al. (27). Briefly, normal term (37-40 weeks of gestation) placentae were obtained immediately after uncomplicated caesarean section. Soft villous tissue chunks $(\sim 30 \mathrm{~g})$ were coarsely minced and rinsed thoroughly in $0.9 \%$ sodium chloride at room temperature. The tissues were then digested in $150 \mathrm{ml}$ calcium- and magnesium-free Hanks' solution (Life Technologies, Middlesex, UK) containing $25 \mathrm{mmol} / \mathrm{l}$ Hepes, 0.125\% trypsin (Sigma Chemical Co., Poole, Dorset, UK) and $0.2 \mathrm{mg} / \mathrm{ml}$ DNase 1 (Sigma) in a shaking water bath at $37{ }^{\circ} \mathrm{C}$ for $45 \mathrm{~min}$. An extra $10 \mathrm{mg}$ DNase 1 were then added and the tissues incubated for a further $10 \mathrm{~min}$. Dispersed cells in the supernatant were collected and $12 \mathrm{ml}$ aliquots were transferred to $15 \mathrm{ml}$ centrifuge tubes containing $1.5 \mathrm{ml}$ fetal calf serum (FCS) to stop the action of trypsin. After centrifugation $(1000 \boldsymbol{g})$ for $5 \mathrm{~min}$, the pellets containing the cells were pooled and resuspended in $5 \mathrm{ml}$ Dulbecco's Modified Eagle's Medium (DMEM; Life Technologies) containing 10\% FCS (supplemented DMEM). Remaining tissue was digested with trypsin and DNase for another $30 \mathrm{~min}$. Finally, the supernatants containing the isolated cells were pooled and centrifuged and the cells resuspended in $5 \mathrm{ml}$ supplemented DMEM. The suspension was layered over a 5-70\% Percoll gradient and centrifuged for $20 \mathrm{~min}$ at $1200 \mathrm{~g}$. The trophoblast cells were collected from the middle layer of the gradient and washed once with supplemented DMEM and resuspended in $1 \mathrm{ml}$ cold PBS containing 1\% BSA. The villous cytotrophoblast were then purified by treating them with immunomagnetic Dynabeads (Dynal UK Ltd., Bromborough, UK) coated with W6/32 (an antibody to HLA class 1) for $30 \mathrm{~min}$ at $4{ }^{\circ} \mathrm{C}$ and passing them over a magnet. All cell types in these preparations other than villous cytotrophoblasts express HLA class 1 antigens and thus this removes the majority of contaminating cells from the cell suspension. After depletion, cells were centrifuged for $2 \mathrm{~min}$ at $11600 \mathrm{~g}$. at $4{ }^{\circ} \mathrm{C}$ and resuspended in supplemented DMEM. Cell viability was checked using trypan blue exclusion.

The purity of the cell preparation was determined by flow cytometry immediately after their purification with the W6/32-coated Dynabeads as described by Kumar et al. (28) using an anti-cytokeratin antibody (JMB2) specific for trophoblasts in this tissue.

Freshly isolated trophoblasts were seeded into 12well culture plates (Flow Laboratories Ltd, Basingstoke, UK) coated with $1 \%$ gelatine (Sigma) at $1 \times 10^{6}$ cells $/ \mathrm{ml}$ per well and cultured with supplemented DMEM at $37{ }^{\circ} \mathrm{C}$ in $5 \% \mathrm{CO}_{2}$.

A serum-free medium (supplemented with $0.5 \mathrm{mg} / \mathrm{ml}$ insulin, $0.5 \mathrm{mg} / \mathrm{ml}$ transferrin and $0.5 \mu \mathrm{g} / \mathrm{ml}$ sodium selenite (Sigma)) was used to avoid the effects of growth factors or hormones in serum which might confound these experiments.

\section{Experimental design}

On day 1 of culture, cells were plated with serum-free culture medium containing different concentrations of the cytokines and growth factors (IL-1 $\beta, \mathrm{TNF}-\alpha$, 
Table 1 Concentrations of the hormones measured ( $n=12$ cultures).

\begin{tabular}{lc}
\hline Hormone & Mean \pm S.D. \\
\hline Inhibin A & $33 \pm 17 \mathrm{pg} / \mathrm{ml}$ \\
Activin A & $609 \pm 199 \mathrm{pg} / \mathrm{ml}$ \\
hCG & $53.2 \pm 36.5 \mathrm{mlU} / \mathrm{ml}$ \\
\hline
\end{tabular}

GMCSF, TGF- $\beta$, inhibin A, activin A and follistatin) to be investigated. All experiments were repeated a minimum of three times with each treatment carried out in triplicate in every culture. The supplemented serum-free DMEM was used as the control medium. Cell culture supernatants were collected after $48 \mathrm{~h}$ and centrifuged at $8900 \boldsymbol{g}$. for $2 \mathrm{~min}$. The supernatant was collected and stored at $-20{ }^{\circ} \mathrm{C}$ until assayed for hCG, inhibin A, activin A and follistatin.

\section{Hormone assays}

Inhibin A Inhibin A was measured using a two-site ELISA that has been previously validated for human granulosa cell culture medium by Muttukrishna et al. $(29,30)$. The minimum detection limit of this assay for human recombinant inhibin A (National Institute for Biological Standards Control (NIBSC), Potters Bar, Herts, UK) was $1 \mathrm{pg} / \mathrm{ml}$. The results were expressed as a percentage of the control. Intra- and interassay variations were 4.5 and $5.1 \%$ respectively.

Activin A Activin A was measured using a two-site ELISA specific for 'total' activin A (follistatin bound+ unbound activin A) as described by Muttukrishna et al. (2). The detection limit of this assay for human recombinant activin A (Genentech Inc., San Francisco, CA, USA) was $50 \mathrm{pg} / \mathrm{ml}$. The results were expressed as a percentage of the control. Intra- and interassay variations were 8.5 and $9.8 \%$ respectively.

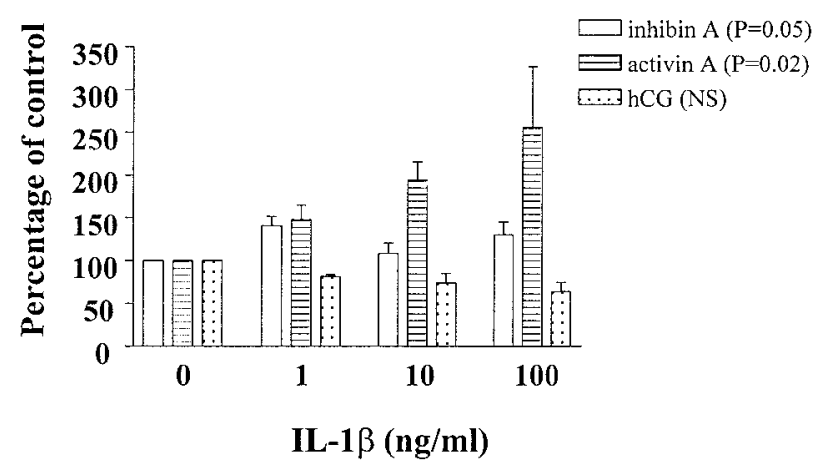

Figure 1 Dose-dependent effect of IL-1 $\beta$ on inhibin A, activin A and hCG. Values are means \pm S.E.M. of three experiments. Statistical analysis of the dose-dependent effect by one-way ANOVA.
Follistatin Follistatins were measured using a two-site ELISA developed by Evans et al. (21). The sensitivity of this assay was $20 \mathrm{pg} / \mathrm{ml}$. The results were expressed as a percentage of control. Intra- and interassay variations were 6.8 and $9.15 \%$ respectively.

hCG hCG was measured using a chemiluminescence assay system (Diagnostic Products Corporation, Los Angeles, CA, USA). The minimum detection limit of this assay was $5 \mathrm{mIU} / \mathrm{ml}$. Mean intra- and interassay variations were 5.6 and $6.2 \%$ respectively.

\section{Statistical analysis}

Data are presented as percentage of control (control values $=100 \%$ ) and represent the means \pm S.E.M. of observations from at least three separate experiments. Data were log transformed to obtain a normal distribution and statistical analysis was carried out using the log-transformed data. One-way ANOVAs with Bonferroni-Dunn post-hoc tests using SPSS 8.0 version for Windows (SPSS Inc., Chicago, IL, USA) were carried out to analyse time- and dose-dependent effects. The level of statistical significance was considered to be $P<0.05$.

\section{Results}

Twenty to thirty million mononuclear trophoblasts were isolated from $\sim 30 \mathrm{~g}$ of villous tissue. The viability of the cells was always $>90 \%$ and the cells were $96.1 \pm 1.1 \%(n=12)$ positive for cytokeratin confirming that they were villous cytotrophoblasts. Absolute levels of inhibin A, activins A and hCG secreted in culture are given in Table $1 \quad(n=12$ cultures). Concentrations of follistatin in the culture media for all experiments were very close to the detection limit of the follistatin assay $(20 \mathrm{pg} / \mathrm{ml})$. Thus follistatin data are not presented.

All data were pooled from replicate cultures $(n=3)$ and the control values were considered as $100 \%$. All other values were normalised against the controls to calculate percentage of control secretion. Therefore, data are presented as percentage of control.

\section{Effect of IL-1及}

Interleukin-1 $\beta(1-100 \mathrm{ng} / \mathrm{ml})$ had a dose-dependent stimulatory effect on inhibin $A(\sim 30 \%, P=0.05)$ and activin $\mathrm{A}(\sim 150 \%, P=0.02)$ secretion. $\mathrm{hCG}$ secretion was not affected by IL-1 $\beta$ (Fig. 1). Follistatin levels were below the detection limit of the assay $(20 \mathrm{pg} / \mathrm{ml})$.

\section{Effect of TNF- $\alpha$}

TNF- $\alpha(1-100 \mathrm{ng} / \mathrm{ml})$ had a dose-dependent stimulatory effect on activin A $(\sim 35 \%, P<0.05)$. hCG secretion was significantly inhibited in a dose-dependent manner 


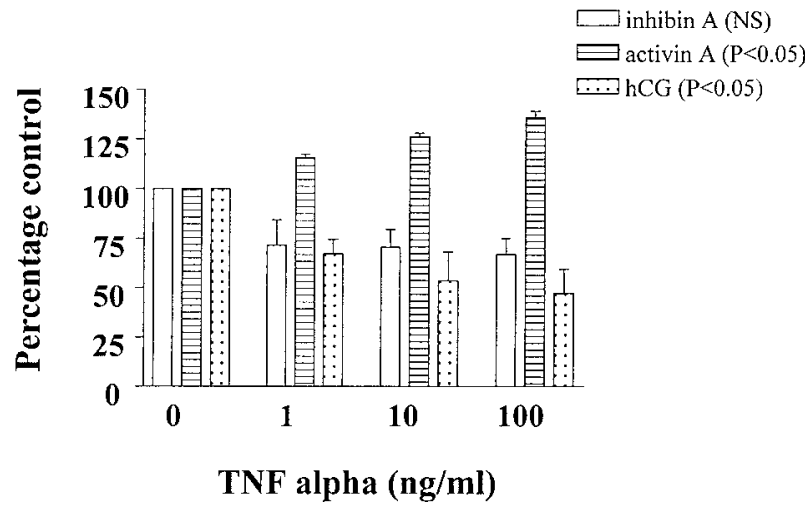

Figure 2 Dose-dependent effect of TNF- $\alpha$ on inhibin A, activin A and hCG. Values are means \pm S.E.M. of three experiments. Statistical analysis of the dose-dependent effect by one-way ANOVA.

$(\sim 50 \%, P<0.05)$. Although TNF- $\alpha$ had a tendency to inhibit inhibin A secretion ( 30\%), this did not reach statistical significance (Fig. 2). Follistatin levels were below the detection limit of the assay $(20 \mathrm{pg} / \mathrm{ml})$.

\section{Effect of GMCSF}

GMCSF (1-100 ng/ml) had a dose-dependent stimulatory effect on activin A $(\sim 100 \%, P<0.01)$. Inhibin A and hCG secretion were not affected by GMCSF (Fig. 3). Follistatin levels were below the detection limit of the assay $(20 \mathrm{pg} / \mathrm{ml})$.

\section{Effect of TGF- $\beta$}

TGF- $\beta$ had no significant effect on activin A, inhibin A and hCG secretion (Fig. 4). Follistatin levels were below the detection limit of the assay $(20 \mathrm{pg} / \mathrm{ml})$.

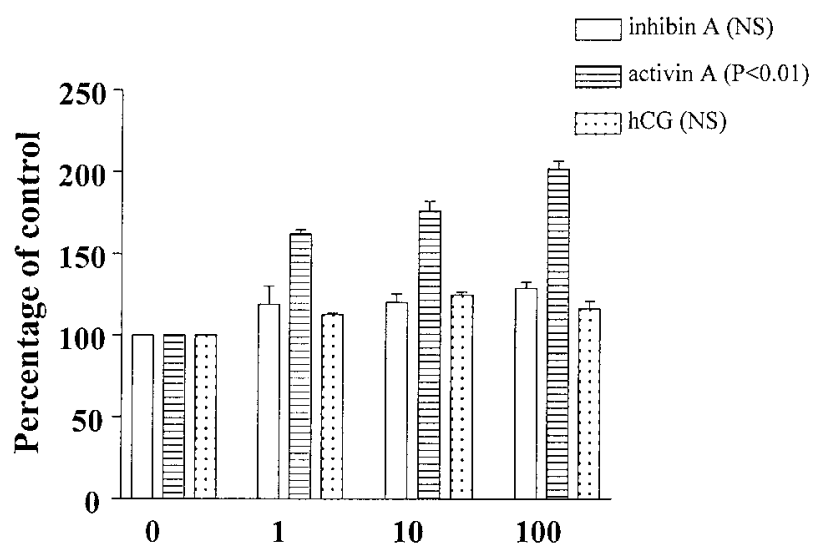

\section{GMCSF (ng/ml)}

Figure 3 Dose-dependent effect of GMCSF on inhibin A, activin A and hCG. Values are means \pm S.E.M. of three experiments. Statistical analysis of the dose-dependent effect by one-way ANOVA.

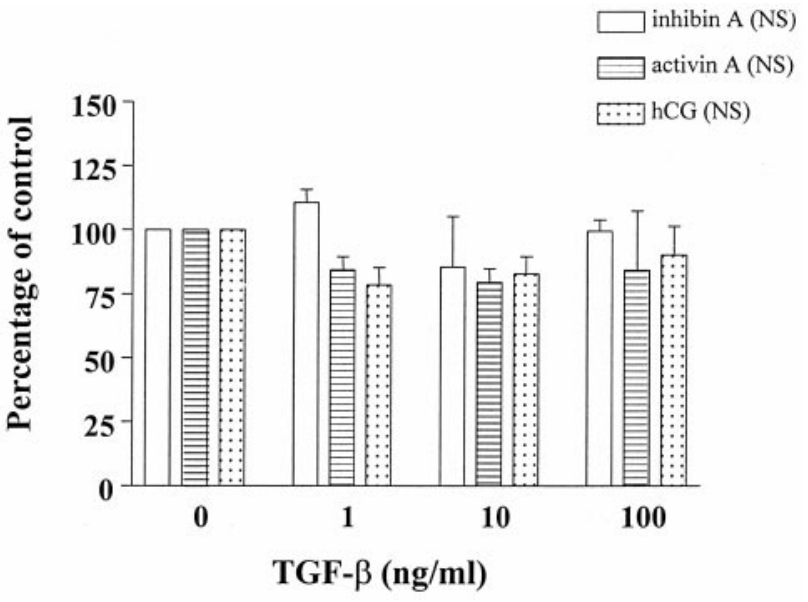

Figure 4 Dose-dependent effect of TGF- $\beta$ on inhibin A, activin A and hCG. Values are means \pm S.E.M. of three experiments. Statistical analysis of the dose-dependent effect by one-way ANOVA.

\section{Effect of inhibin $A$, activin $A$ and follistatin}

Inhibin A, activin A and follistatin did not have a significant effect on the secretion of activin A, inhibin A and hCG respectively (Fig. 5). Follistatin levels were below the detection limit of the assay $(20 \mathrm{pg} / \mathrm{ml})$.

\section{Discussion}

There is growing evidence that the placenta, and more specifically the trophoblast, is the source of maternal circulating inhibin A and activin A. Petraglia et al. (31) reported that at term, inhibin $\alpha$-subunit was localised in the cytotrophoblast, inhibin $\beta B$-subunit was observed in the syncytial layer of the villi and inhibin $\beta A$-subunit was widely distributed in both cell types. However, a recent study using a monoclonal antibody against inhibin $\alpha$-subunit has reported more intense staining in the syncytiotrophoblast in early pregnancy than in mature chorionic villi from third-trimester gestations. There was weak staining in the villous cytotrophoblast and decidua (32). Minami et al. (33) also reported positive immunostaining for inhibin subunits in the syncytiotrophoblast but not in the villous cytotrophoblast. Thus, there is some confusion as to which trophoblast population is the source of these proteins. Follistatin has also been previously localised to the extra-placental membranes and placental syncytiotrophoblast at term by immunofluorescence (34) and has been identified in placental homogenates by chromatography and immunoassay (35). Petraglia et al. (34) have measured the secretion of ir-follistatin by placental trophoblasts in culture for 5-6 days in the presence of serum.

This is the first study to investigate the effect of these proinflammatory cytokines on inhibin A and follistatin secretion by trophoblasts in culture. We have shown 

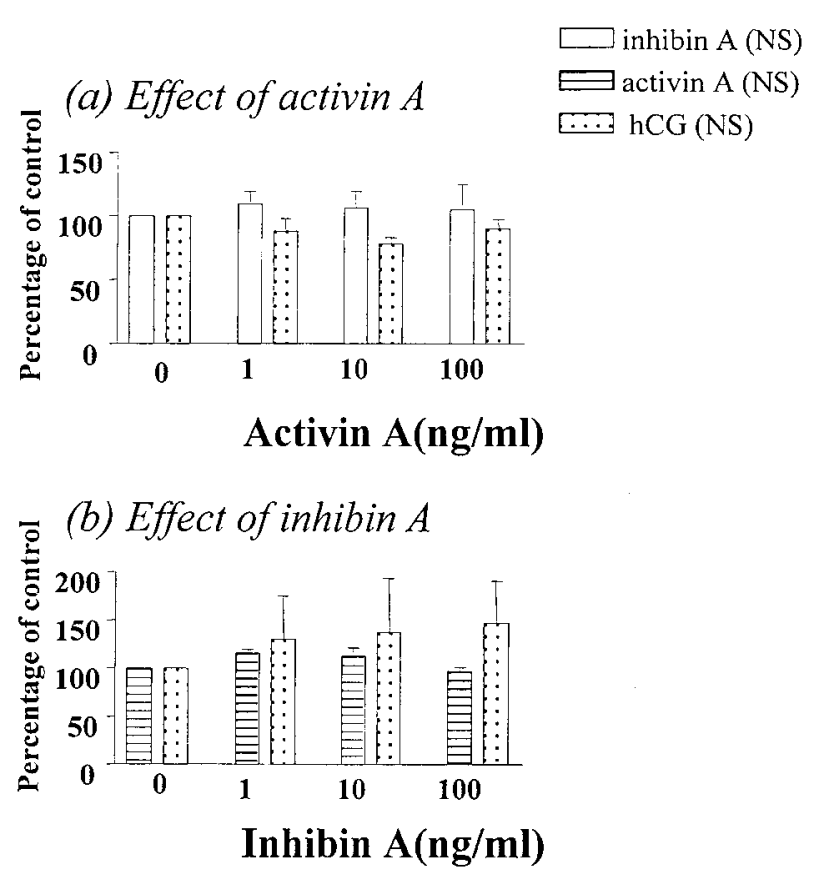

(c) Effect of follistatin

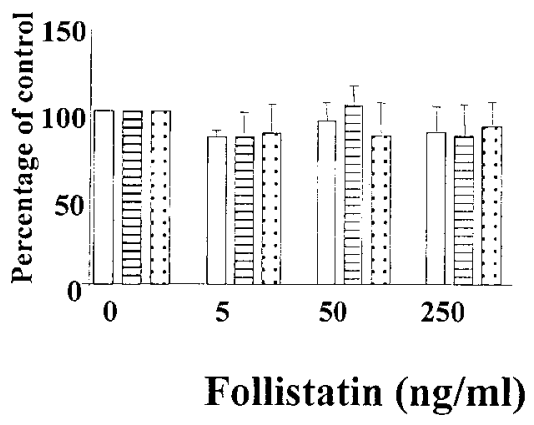

Figure 5 Dose-dependent effect of (a) activin A, $(b)$ inhibin $A$ and (c) follistatin on inhibin A, activin A and hCG. Values are means \pm S.E.M. of three experiments. Statistical analysis of the dosedependent effect by one-way ANOVA.

previously that maternal serum inhibin $A$ and activin A are raised in pre-eclampsia (7), a maternal disease in which circulatory levels of inflammatory cytokines are also raised (26). Therefore, we sought to determine whether these cytokines have any effect on activin A, inhibin A and follistatin secretion by trophoblasts. This study has shown that inflammatory cytokines TNF- $\alpha$ and IL-1 $\beta$ stimulate activin $A$, in agreement with Keelan et al. (36). Inhibin A secretion is modestly stimulated by IL-1 $\beta$ but not by TNF- $\alpha$, suggesting differential regulation of production of inhibin $A$ and activin A by the trophoblasts. TNF- $\alpha$ had a significant inhibitory effect on hCG.

Morrish (26) has reported that TGF- $\beta$ inhibits and GMCSF stimulates the formation of syncytia in cytotrophoblast cultures. Our study shows that GMCSFstimulated activin $A$ and TGF- $\beta$ had no effect on inhibin A or activin A secretion, suggesting that these proteins are secreted by cytotrophoblasts as well as syncytiotrophoblasts. Autocrine/paracrine effects of inhibin A, activin A and follistatin were studied to investigate if these proteins were responsible for the rise in activin $A$ and inhibin $A$ in pre-eclampsia. These growth factors did not significantly alter the secretion of inhibin A, activin A or hCG in culture. Samples were assayed for follistatin to determine whether the activin A secreted by these cells was 'free' or bound to follistatin. However, follistatin levels were below the limit of detection in all these culture samples, suggesting that all secreted activin A was 'free' and potentially bioactive. Studies are now being carried out to measure the bioactivity of these samples using a murine plasmocytoma cell line, T-10.

Qu et al. (17) have shown that ir-inhibin is present in serum-free trophoblast culture, but they used the Monash assay that cannot distinguish between inhibin dimers and the inert monomeric $\alpha$-subunit. Keelan et al. (22) also measured ir-inhibin and inhibin/activin subunit proteins by the Western blotting technique in term villous trophoblast culture medium.

Activin has been reported to exert a stimulatory effect on gonadotrophin-releasing hormone and hCG secretion from the placenta (37). Similarly, recent studies by Song et al. (38) have shown that treatment of villous trophoblast cultures with activin A has a stimulatory effect on hCG production. However, we find that activin A treatment has no significant effect on hCG or inhibin A secretion and the difference may be due to the different culture conditions. Our study, consistent with previous observations, suggests that cytotrophoblasts differentiate into syncytiotrophoblasts in culture as determined by hCG secretion. The lack of effect of cytokines on follistatin may be due to the inability to detect follistatin $(<20 \mathrm{pg} / \mathrm{ml})$ secretion by trophoblasts. The follistatin assay used in this study essentially detects follistatin 288 (FS288) and has considerable cross-reaction with follistatin 315 (FS315; $9.9 \%$ ). FS315 is reported to be the major follistatin form in the human circulation (39). In the previous study, 1-2 $\mathrm{ng} / \mathrm{ml}$ ir-follistatin have been measured in culture media on day 5-6 of culture in the presence of $20 \%$ serum (34). This study was carried out with a highly pure population of cytotrophoblasts $(>96 \%)$ in culture in the absence of serum for 2 days. The inability to detect follistatin from the culture media could be due to the different culture conditions (media and time) and/or the limitation of the ELISA in predominantly measuring FS288.

The presence of high concentrations of inhibin A and activin $\mathrm{A}$ in maternal circulation and the secretion by the villous trophoblasts suggests that these proteins may have a physiological function in pregnancy. Activin A also increases the release of ir-oxytocin from the placental trophoblast (40) suggesting that activin A may be involved in parturition at term. 
The effects are not restricted to the third trimester, as addition of activin A but not inhibin A to first-trimester chorionic villi explants stimulates the outgrowth of cytotrophoblast into the surrounding matrix. Addition of follistatin reversed these effects of activin A, suggesting that activin A promotes growth and differentiation in the villous cytotrophoblast in the first trimester (41).

In summary, we have shown for the first time that IL$1 \beta$ stimulates inhibin A and confirmed that inflammatory cytokines significantly stimulate the secretion of activin $A$. We speculate that the increase in trophoblast secretion of activin $A$ in the presence of inflammatory cytokines could be a possible mechanism for the rise in serum activin A in pre-eclampsia. The release of this activin $\mathrm{A}$ into the maternal circulation may play a role in the systemic inflammatory response seen in preeclampsia, which is thought to be the cause of the maternal syndrome (25). In contrast, inhibin A was stimulated modestly by IL-1 $\beta$ and not by other cytokines, indicating that the mechanisms involved in the rise of activin $\mathrm{A}$ and inhibin $\mathrm{A}$ in pre-eclampsia are controlled differentially.

\section{Acknowledgements}

S M and this project were supported by the Wellcome Trust. We thank the NIBSC for the human recombinant inhibin A standard, and Genentech Inc. for the human recombinant activin A standard used in the assay.

\section{References}

1 Muttukrishna S, George L, Fowler PA, Groome NP \& Knight PG. Measurement of serum concentrations of inhibin $A\left(\alpha-\beta_{A}\right.$ dimer) during human pregnancy. Clinical Endocrinology 199542 391-397.

2 Muttukrishna S, Fowler PA, George L, Groome NP \& Knight PG. Changes in peripheral serum levels of 'total' activin A during the human menstrual cycle and pregnancy. Journal of Clinical Endocrinology and Metabolism $1996 \mathbf{8 1} 3328-3334$.

3 Birdsall M, Ledger W, Groome N, Abdalla H \& Muttukrishna S. Inhibin A activin A in the first trimester of human pregnancy. Journal of Clinical Endocrinology and Metabolism 199782 1557-1560.

4 Muttukrishna S, Child TJ, Groome NP \& Ledger WL. The source of circulating levels of inhibin A, pro-alpha $\mathrm{C}$ containing inhibins and activin A in early pregnancy. Human Reproduction 199712 1089-1093.

5 Lockwood GM, Ledger WL, Barlow DH, Groome NP \& Muttukrishna S. Measurement of inhibin and activin in early human pregnancy: demonstration of feto-placental origin and role in prediction of early pregnancy outcome. Biology of Reproduction 199757 1490-1494.

6 Fowler PA, Evans LW, Groome NP, Templeton A \& Knight PG. A longitudinal study of maternal serum inhibin-A, inhibin-B, activin-A, activin- $A B$, pro-alphaC and follistatin during pregnancy. Human Reproduction 199813 3530-3536.

7 Muttukrishna S, Knight PG, Groome NP, Redman CWG \& Ledger WL. Inhibin A activin A: new endocrine markers for pre-eclampsia? Lancet 1997349 1285-1288.

8 Mayo KE, Cerelli GM, Spiess J, Rivier J, Rosenfeld MG, Evans RM et al. Inhibin-A subunit cDNAs from porcine ovary and human placenta. PNAS $1986 \mathbf{8 3} 5849-5853$.
9 McLachlan RI, Healy DL, Robertson DM, Burger HG \& Kretser DM. The human placenta: novel source of inhibin. Biochemical and Biophysical Research Communications 1986140 485-490.

10 Baird DT \& Smith KB. Inhibin and related peptides in the regulation of reproduction. Oxford Reviews of Reproductive Biology $199315191-232$.

11 Petraglia F, Garuti GC, Calza L, Roberts V, Giardino L, Genazzani AR et al. Inhibin subunits in human placenta: localization and messenger ribonucleic acid levels during pregnancy. American Journal of Obstetrics and Gynecology 1991 $165750-758$.

12 Tovanabuttra S, Reddi K, Norman JE, Ledger WL, McNeilly AS \& Baird DT. Immunoreactivity and bioactivity of inhibin-like substance in human placenta throughout pregnancy. Journal of Endocrinology 126 Suppl 1990137 (Abstract).

13 Findlay JK, Xiao S, Shukovski \& Michel U. Novel peptides in ovarian physiology: inhibin, activin and follistatin. In The Ovary, pp 413-432. New York: Raven Press, 1992.

14 Mather JP, Woodruff TK \& Krummen LA. Paracrine regulation of reproductive function by inhibin and activin. Proceedings of the Society for Experimental Biology and Medicine 1992201 1-15.

15 Keelan J, Song Y \& France JT. Comparative regulation of inhibin, activin and human chorionic gonadotropin production by placental trophoblast cells in culture. Placenta 199415 803-818.

16 Robertson DM, Foulds LM, Leversha L, Morgan FJ, Hearn MT, Burger HG et al. Isolation of inhibin from bovine follicular fluid. Biochemical and Biophysical Research Communications 1985126 220-226.

17 Qu J, Ying S-Y \& Thomas K. Inhibin production and secretion in human placental cells cultured in vitro. Obstetrics and Gynaecology $199279705-712$.

18 Groome NP, Illingworth PJ, O'Brien M, Cooke I, Ganeison TS, Baird DT et al. Detection of dimeric inhibin throughout the human menstrual cycle by two-site enzyme immunoassay. Clinical Endocrinology $1994 \mathbf{4 0} 717-723$.

19 Groome NP, Illingworth PJ, O’Brien M, Rodger FE, Mather J \& McNeilly AS. Measurement of dimeric inhibin-B throughout the human menstrual cycle. Journal of Clinical Endocrinology and Metabolism 199681 1401-1405.

20 Knight PG, Muttukrishna S \& Groome NP. Development and application of a two-site enzyme immunoassay for the development of total activin A concentrations in serum and follicular fluid. Journal of Endocrinology 1996148 267-279.

21 Evans LW, Muttukrishna S \& Groome NP. Development, validation, and application of an ultra sensitive two-site enzyme immunoassay for human follistatin. Journal of Endocrinology $1998156275-282$.

22 Keelan J, Song Y \& France JT. Comparative regulation of inhibin, activin and human chorionic gonadotropin production by placental trophoblast cells in culture. Placenta 199415 803-818.

23 Asselin J, Redman C, Sargent IL, Groome NP \& Muttukrishna S. Secretion of inhibin A and activin A by cultured term placental trophoblasts from normal and pre-eclamptic women. Placenta 199920 A12 (Abstract).

24 Asselin J, Mohan A, Sargent IL, Groome N \& Muttukrishna S. Secretion of inhibin A and activin A by term placental trophoblasts in culture. Inhibin, Activin and Follistatin Workshop, Melbourne, Australia, October 2000 (Abstract).

25 Redman CWG, Sacks GP \& Sargent I. Pre-eclampsia: an excessive maternal inflammatory response to pregnancy. American Journal of Obstetrics and Gynaecology $1999 \mathbf{1 8 0} 499-506$.

26 Morrish D, Dakour J \& Li H. Functional regulation of human trophoblast differentiation. Journal of Reproductive Immunology $199839179-195$.

27 Kliman HJ, Nestler JE, Sermasi E, Sanger JM \& Strauss JF III. Purification, characterization, and in vitro differentiation of cytotrophoblasts from human term placentae. Endocrinology $19861181567-1582$. 
28 Kumar S, Kniss DA, Linton EA, Sargent I \& Redman CWG. Characterisation and comparison of villous cytotrophoblasts prepared by the Kliman method and the ED27 Cell line. Placenta 199920 A39 (Abstract).

29 Muttukrishna S, Fowler PA, Groome NP, Mitchell GG, Robertson WR \& Knight PG. Serum concentrations of dimeric inhibin during spontaneous human menstrual cycle and after treatment with exogenous gonadotrophin. Human Reproduction $199491634-1642$.

30 Muttukrishna S, Groome N \& Ledger WL. Gonadotropic control of secretion of dimeric inhibins and activin A by human granulosa-luteal cells in vitro. Journal of Assisted Reproduction and Genetics $1997 \mathbf{1 4}$ 566-573.

31 Petraglia F, Garuti GC, Calza L, Roberts V, Giardino L, Genazzani AR et al. Inhibin subunits in human placenta: localization and messenger ribonucleic acid levels during pregnancy. American Journal of Obstetrics and Gynecology 1991 $165750-758$.

32 McCluggage WG, Ashe P, McBride H, Maxwell P \& Sloan JM. Localization of the cellular expression of inhibin in trophoblastic tissue. Histopathology 199832 252-256.

33 Minami S, Yamoto M \& Nakano R. Sources of inhibin in early pregnancy. Early Pregnancy 19951 62-66.

34 Petraglia F, Gallinelli A, Grande A, Florio PFS, Gennazzani AR, Ling $\mathrm{N}$ et al. Local production and action of follistatin in human placenta. Journal of Clinical Endocrinology and Metabolism 1994 78 205-210.

35 de-Kretser DM, Foulds LM, Hancock M \& Robertson DM. Partial characterization of inhibin, activin, and follistatin in the term human placenta. Journal of Clinical Endocrinology and Metabolism $199479502-507$.

36 Keelan JL, Groome N \& Mitchell M. Regulation of activin A production by human amnion, decidua and placenta in vitro by pro-inflammatory cytokines. Placenta 199819 429-434.

37 Petraglia F, Vaughan J \& Vale W. Inhibin and activin modulate the release of gonadotropin-releasing hormone, human chorionic gonadotropin, and progesterone from cultured human placental cells. PNAS $1989 \mathbf{8 9} 5114-5117$.

38 Song Y, Keelan J \& France JT. Activin-A stimulates, while transforming growth factor beta 1 inhibits, chorionic gonadotrophin production and aromatase activity in cultured human placental trophoblasts. Placenta 199617 603-610.

39 Schneyer AL, Hall HA, Lambert-Messerlian G, Wang QF, Sluss P \& Crowley WF. Follistatin activin complexes in human serum and follicular fluid differ immunologically and biochemically. Endocrinology 1996137 240-247.

40 Florio P, Lombardo M, Gallo R, Di Carlo C, Sutton S, Genazzani AR et al. Activin A, corticotropin-releasing factor and prostaglandin F2 alpha increase immunoreactive oxytocin release from cultured human placental cells. Placenta $1996 \mathbf{1 7}$ 307-311.

41 Caniggia I, Lye SJ \& Cross JC. Activin is a local regulator of human cytotrophoblast cell differentiation. Endocrinology 1997 138 3976-3986.

Received 26 February 2001

Accepted 16 May 2001 